\title{
Primary Cutaneous B-Cell/T-Cell (Non- MF/SS) Lymphoma T1a TNM Finding v8
}

National Cancer Institute

\section{Source}

National Cancer Institute. Primary Cutaneous B-Cell/T-Cell (Non-MFISS) Lymphoma T1a

TNM Finding v8. NCI Thesaurus. Code C141384.

Solitary lesion measuring less than $5 \mathrm{~cm}$. (from AJCC 8th Ed.) 